\title{
COMPARATIVE ANALYSIS OF THE TEACHERS’ MIGRATION
}

\author{
ANÁLISE COMPARATIVA DA PESQUISA RUSSA E ESTRANGEIRA DA MIGRAÇÃO \\ DE PROFESSORES
}

\author{
ANÁLISIS COMPARATIVO DE LA INVESTIGACIÓN RUSA Y EXTRANJERA SOBRE \\ LA MIGRACIÓN DOCENTE
}

\author{
Iuliia KOLESNIKOVA ${ }^{1}$ \\ Alla BOGOMOLOVA ${ }^{2}$ \\ Nina FEDINA ${ }^{3}$ \\ Irina BURMYKINA ${ }^{4}$ \\ Dmitry KATAEV ${ }^{5}$ \\ Anastasia ZEMLYANSKAYA ${ }^{6}$
}

\begin{abstract}
This article analyses Russian and foreign academic research in the field of teacher migration. The study aims to determine the volume of research on the given subject area. We have used a comparative and structural-functional analysis and statistical means. The objectives were to study the concept of migration, to identify positive and negative aspects of labor migration, to examine the meaning of the terms of educational and intellectual migration, to identify the problems faced by teachers when moving to other countries based on the works of foreign authors. The teachers' experience in such countries as the USA, Belgium, and Norway was analyzed for this purpose. The main results of the study confirm the relevance of the article's topic. We came to the conclusion that the narrow focus "migration of teachers" is barely studied and requires additional research to identify the causes and factors in the teacher professional activities.
\end{abstract}

KEYWORDS: Labor migration. Educational migration. Intellectual migration.

${ }^{1}$ Lipetsk State Pedagogical P. Semenov-Tyan-Shansk University, Lipetsk - Russia. Associate Professor of the Department of Sociology and Management. Candidate of Economic Sciences. ORCID: https://orcid.org/00000002-5722-1512. E-mail: Iuliia.kolesnikova-researcher@yande.ru

${ }^{2}$ Lipetsk State Pedagogical P. Semenov-Tyan-Shansky University, Lipetsk - Russia. Associate Professor, Head of the Department of Sociology and Management. Candidate of Sociological Sciences. ORCID: https://orcid.org/0000-0001-9017-8651. E-mail: allabogomolova@internet.ru

${ }^{3}$ Lipetsk State Pedagogical P. Semenov-Tyan-Shansky University, Lipetsk - Russia. Associate Professor, Rector. Candidate of Pedagogical Sciences. ORCID: https://orcid.org/0000-0002-9026-1161. E-mail: ninafedina@ro.ru

${ }^{4}$ Lipetsk State Pedagogical P. Semenov-Tyan-Shansky University, Lipetsk - Russia. Professor in the Department of Sociology and Management. Doctor of Sociological Sciences. ORCID: https://orcid.org/0000-0002-4145-5859. E-mail: burmykinairina@yandex.ru

${ }^{5}$ Lipetsk State Pedagogical P. Semenov-Tyan-Shansky University, Lipetsk - Russia. Associate Professor, Professor of the Department of Sociology and Management. Doctor of Sociological Sciences. ORCID: https://orcid.org/0000-0003-4391-8949. E-mail: dmitrykataev@rambler.ru

${ }^{6}$ Lipetsk State Pedagogical P. Semenov-Tyan-Shansky University, Lipetsk - Russia. Professor of the Department of Sociology and Management. PhD in Sociological Sciences. ORCID: https://orcid.org/0000-0002-8506-2627. E-mail: anastasiazemlyanskaya@mail.ru 
RESUMO: Este artigo analisa pesquisas acadêmicas russas e estrangeiras no campo da migração de professores. O objetivo do estudo é determinar o volume de pesquisas sobre a área do sujeito. No artigo, utilizou-se uma análise comparativa das fontes, bem como métodos como análise comparativa e estrutural-funcional e meios estatísticos. Os objetivos foram estudar o conceito de migração, identificar aspectos positivos e negativos da migração do trabalho, examinar o significado dos termos de migração educacional e intelectual, identificar os problemas enfrentados pelos professores ao se deslocarem para outros países com base nos trabalhos de autores estrangeiros. A experiência dos professores em países como EUA, Bélgica e Noruega foi analisada para esse fim. Os principais resultados do estudo confirmam a relevância do tema. Chegamos à conclusão de que o foco "migração de professores" é pouco estudado e requer pesquisas adicionais para identificar as causas e fatores nas atividades profissionais do professor.

PALAVRAS-CHAVE: Migração de mão de obra. Migração educacional. Migração intelectual.

RESUMEN: Este artículo analiza la investigación académica rusa y extranjera en el campo de la migración docente. El estudio tiene como objetivo determinar el volumen de investigación sobre el área temática dada. Hemos utilizado métodos de análisis comparativo y estructuralfuncional, y medios estadísticos. Los objetivos fueron estudiar el concepto de migración, identificar aspectos positivos y negativos de la migración laboral, examinar el significado de los términos de migración educativa e intelectual, identificar los problemas que enfrentan los docentes al trasladarse a otros países a partir de las obras de autores extranjeros. Para ello se analizó la experiencia de los docentes en países como Estados Unidos, Bélgica y Noruega. Los principales resultados del estudio confirman la relevancia del tema. Llegamos a la conclusión de que el enfoque estrecho "migración de maestros" apenas se estudia y requiere investigación adicional para identificar las causas y los factores en las actividades profesionales de los maestros.

PALABRAS CLAVE: Migración laboral. Migración educativa. Migración intelectual.

\section{Introduction}

In the modern social and economic conditions, the migration of a skilled labor force is an essential problem. To date, there is no unified approach to the definition of "teacher migration". The purpose of this research paper is to compare the analysis performed by foreign and Russian academic research on teacher migration. The objectives of the paper are: to identify key problems of teacher migration; to analyze scientific research of Russian authors devoted to the chosen topic; and to study scientific works of foreign scholars. The relevance of this study is determined by the lack of research in the context of specific professional activities. Studies by both foreign (BAUMAN, 2018; BOURDIEU, 2017; CASTELLS, 2020; MCKENZIE; STILLMAN; GIBSON, 2010) and Russian scholars (DOLZHIKOVA, 2020; KOVALEV, 2017; TSKHADADZE; SKRYABIN, 2020) are mostly focused on labor migration, educational 
and intellectual migration and teacher mobility. Sorokin (2005) introduces a definition of social migration. A comparative analysis of the literature reveals that issues related to intellectual, educational migration and migration mobility are widely covered, while research on teacher migration is studied insufficiently. The very concept of teacher migration does not exist. Lots of academic works are devoted to the concept of migration in general, and in researching this topic we understand that teacher migration is about the movement of teachers, defining the framework of professional activity and examining the causes.

In a modern country, one of the factors determining economic well-being is the predominance of high-qualified personnel, who are the foundation of socioeconomic development. There are several levels of education in the Russian Federation: preschool education; school education (primary, secondary basic, complete secondary education); vocational education (vocational schools, specialized secondary schools, higher education institutions); and postgraduate education (postgraduate, doctoral studies). Teachers involved in the educational process are guides for future school graduates. Nevertheless, this profession is not considered prestigious in Russia. However, it is the school that lays the foundation of knowledge in every pupil. Despite the importance of the profession, there are a number of problems in Russia that force teachers to either leave the profession or migrate to other regions and countries, including the following:

- $\quad$ ill-conceived management system;

- low salaries;

- $\quad$ low teacher status;

- $\quad$ outdated facilities.

All these factors provoke young personnel to either change their professional activities or move to other regions, countries. Thus, they can get a chance to increase their financial independence and level up social status.

According to Rosstat, there are 164 higher educational establishments in 133 cities of the Russian Federation, offering teacher training to university entrants. Irrational migration of teachers reduces the human resources potential of the region. It should be noted that budget financing of teacher education in the Russian Federation accompanied with such phenomenon as migration can also be attributed to irrational. It is so because the spent monetary resources do not correspond to target indicators, namely, renewal of pedagogical staff in general 
education. That is why teacher migration at the present historical stage is one of the relevant phenomena for research.

\section{Materials and methods}

To reach the goal of this study, we used mainly theoretical methods: comparison, structural-functional method, and analysis. The comparative method is based on the comparison of two or more ideas, highlighting the commonalities and differences in them for the purpose of creation of typology.

We have used this method to compare a number of scientific terms such as: labor migration, professional mobility, educational and intellectual mobility. Labor mobility and occupational mobility can be defined to refer to all types of occupations, while the latter two are more related to education. As mentioned above, we are interested in general education, namely teachers and the migration processes that are associated with them. There are many academic papers devoted to the concept of migration.

The phenomenon of migration is a multifaceted and complex process. Kovalev (2017) in his research determines that everyone is inherently a migrant: the one who is undergoing training (educational migration), moving to a place of work (pendular migration), organizing recreation (seasonal migration). When it comes to scientific personnel, we can talk about the concept of intellectual migration. Dolzhikova (2020) classifies intellectual migration in a narrow sense: that is, migration of scientists and researchers; in a broad sense, migration flows of high-qualified personnel.

Tskhadadze and Skryabin (2020) identified the ancestor of migration overpopulation in his research. The British scientist Ravenstein was the founder of the scientific study of migration and the author of The Eleven Laws of Migration. In 1885, he regarded migration as a permanent process within society aimed at territorial movements and involving temporary changes.

The term social mobility was introduced by Sorokin (2005). He referred to social mobility as the movement of an individual from one social situation to another. Sorokin talked about individual (career) and group (migration) social mobility. Naturally, the process of group mobility is more complex. The reasons for mass movements should be sought in changes in the economic sphere, a political upheaval or a change of ideological reference points. Vertical group-based social mobility introduces major changes to the stratification structure, changing the existing hierarchy. 
Moiseenko (2004, our translation) considered the migration process as "a form of population movement in which a change of place of residence, defined by a temporary equivalent and accompanied by specific consequences".

Vechkanov defines the term migration as the conditions for a change of permanent place of residence subsequently with the implementation of labor activities, taking into account societal needs (TSKHADADZE; SKRYABIN, 2020).

In order to determine to what extent teacher migration will have an impact on the social and economic situation in the country, we used the structural-functional method, which helps to determine the formations of labor migration.

Having defined the concept of migration, let us consider the term labor migration. Utkina and Sliusarenko (2016) believe that the trigger for the formation of labor migration in the state is a continuous search by the labor force for a more profitable place of work to implement financial and personal needs.

The positive aspects of labor migration include:

- $\quad$ improved quality of life;

- lowering of unemployment rate;

- the human resources reserve is being replenished;

- $\quad$ savings in the training of incoming citizens;

- $\quad$ rise of taxable base;

- $\quad$ an increase in consumers.

Drawbacks to the emergence of labor migration are:

- ethnic conflict situations;

- competition for jobs;

- lower average wages.

Educational migration can be considered a type of migration: spatial movements of people directly involved in the process of intellectual emigration (UTKINA; SLIUSARENKO, 2016).

The emergence of teacher migration is associated with risks and uncertainties caused by the processes of educational transformation, as well as living conditions. Being in a risk environment, young personnel build their own educational trajectory aimed at preventing and overcoming possible risks. 
As part of his research project, Savenkov (2016) identifies the following reasons for migration: leaving for small and medium-sized businesses; going to other regions; and going abroad. Thus, among the main reasons for the outflow of teachers prevail: low wages, lack of housing conditions, outdated methodological base, lack of prospects, weak support from the state.

On October 18, 2013, the Russian Ministry of Labor and Social Protection approved the professional standard teacher, which states that "a teacher is a key figure in the educational reform". Among other things, the standard defines that a professional teacher possesses readiness for change, mobility, responsibility in personal decisions. A successful modern teacher should be constantly engaged in self-development and self-improvement, to realize their potential, and to be able to use innovative technologies.

The difference between migration and professional mobility lies in the fact that the first concept is associated with the relocations of an individual, both over short and long distances. Professional mobility is interpreted as an individual's readiness and ability to quickly master new technologies and acquire missing knowledge in order to enhance personal professional performance. That is, the second concept is related to the profession of a person who seeks a higher status in society.

Using the method of analysis, let us define the professional mobility of a teacher. The analysis allows us to divide the process into its components and to highlight its individual attributes.

In this regard, professional mobility of teachers will allow them to gain new experience not only within the country, but also in a global scale. This topic was studied in the works of Nuzhnova (2019), Igoshev (2016), Zheltov and Skornyakov (2008), Skornyakova (2008), Vershinina (2006), and Pronchev et al. (2019). Migration of teachers as a process was analyzed by Shcherbakov et al. (2017), Volkov (2009), and others.

The research identified vertical and horizontal mobility vectors, which are described in the works of Sorokin (2005), Goryunova (2006), Amirova and Khramova (2016), and others.

Teacher mobility is determined by personal characteristics, which include flexibility, creativity, innovativeness, adaptability, social activity. The personal qualities of professional mobility are reflected in the scientific works of Nuzhnova (2019), Gaga (2008), Tskhadadze and Skryabin (2020).

Theories and concepts of personnel mobility, socioprofessional mobility have been studied by Sorokin (2005), Gimpelson and Kapelyushnikov (2017), Igoshev (2016), Bondyreva and Kolesov (2007), Malyshev (2015). 
Based on the works of the above-mentioned researchers, we can identify the criteria of teacher professional mobility.

Value and motivational:

- inner motivation for professional development (self-improvement, self-discovery);

- $\quad$ vertical vector (career growth);

- motivation for continuous learning;

- focus on success.

\section{Cognitive:}

- the ability to solve and overcome professional challenges;

- the use of innovative tools;

- mastering of new competencies;

- knowledge in personal professional field.

Personal and meaningful:

- $\quad$ adapting to the new environment;

- demonstrating engagement in professional activities;

- creative approach;

- responsibility in decision-making;

- communicativeness and establishment of new contacts with the subjects of educational activity.

Thus, teacher migration is influenced by: the duration of work, the level of professional training, the discipline taught, social and demographic characteristics of the individual. Academics also single out the subjective factor, such as: job satisfaction, productivity.

The analysis of foreign scholars on the study of teacher migration is mainly confined to identifying the problem associated with this process.

\section{The problem of social inequality of teachers in connection with educators within}

the boundaries of the country. This issue has been studied in the works of social reproduction, such as Bourdieu (2017), who studied social capital and class reproduction; Castells (2020) with information society theory; and Bauman (2018) who studied the impact of globalization on personality. Many researchers indirectly touched upon the topic, denoting that migration 
forces a teacher to be on starting conditions, as they lack social characteristics in the new society, there are limited monetary resources, insufficient knowledge of the host language.

2. Age. It is believed that the earlier the migration process takes place, the better for the teacher. Nevertheless, in the works of McKenzie, Stillman and Gibson (2010), it is determined that early migration will not allow an educator to become more professional in the field.

3. Stigma effect. The issue of racial discrimination becomes controversial, as a teacher will belong to their own race, which may lead to prejudice and intolerance, as well as isolation of a migrant teacher from the natives.

4. Adaptation. In the analysis of Western researchers there is a strategy of migrant teacher adaptation: transitional, adaptive, bicultural. Transitional adaptation begins at the initial stage; adaptive, when the individual establishes communication ties, as a result there is a concentration of communication. Bicultural adaptation includes adherence to the culture and traditions of the host and own ethnic group. The paper also used the statistical method, the data obtained in the analysis reflect the dynamics of the teaching profession abroad: in Belgium, USA, and Norway.

\section{Results}

Thus, having analyzed the foreign experience of scientists devoted to the study of teacher migration, we can say that the statistics collected in 50 American states by the National Center for Education Statistics can be divided into several cycles. In our study, we conclude that $11 \%$ of teachers leave the profession within the first year, and $39 \%$ of respondents within five years. Analysis in the school system in Belgium shows that four out of ten teachers leave the teaching profession in the first five years of their career. The findings indicate that there is a teacher shortage in certain subjects. These results raise questions about the analysis of teachers' professional trajectories and probably indicate a loss in the overall attractiveness of the profession. This phenomenon is not new and many authors see it as a consequence of the deinstitutionalization of the school. Other authors have addressed this issue through the prism of teachers' professional identity, the growing complexity of the profession or its relative attractiveness compared to other professions.

A comparative literature review found that some teachers are withdrawing from their responsibilities due to professional or personal reasons. A study of primary and lower secondary school teachers in Norway, for instance, highlighted that women of childbearing age were more likely to leave the profession. This behavior is facilitated by policies in Norway and more 
generally in the Nordic countries that encourage interrupting careers to bring up their own children. The rate of exit from the profession increases again when we consider the most experienced staff who leave their teaching load due to retirement age. For example, this rate in the United States was $12 \%$ of total staff turnover. Johnson and Salt (2018) found that educator job satisfaction is related to internal and external resources. The former include the teacher's personal characteristics and professional achievements. The latter include salary and career development.

That is how we have come to a conclusion that such analyses are relevant and require deepening, designed to better understand what the social perceptions pertaining to the profession are and the factors, both objective and subjective, that today slow down or encourage teacher training graduates to enter and continue in the profession. However, they offer only a general assessment of the situation throughout the territory. The line of research developed over one or two decades tends to show that the phenomenon of teacher migration deserves to be studied at other levels and, in particular, in relation to the schools in which they practice. Until the early 2000s, the predominant point of analysis focused on individuals and sought to determine the extent to which teachers' professional trajectories were shaped by a number of individual factors (gender, work experience, discipline taught, etc.). Since then, there has been a major shift towards an approach which also takes into account the characteristics of organizations and the work environment. Job satisfaction and dissatisfaction are complex emotional responses that arise from the interaction between the employee and the work setting in which they work. They are related to the evaluation that employees make between what they want professionally and what their jobs give them. This evaluation process is defined by three elements. It is about the individual's perception of aspects of work, their values and standards, and finally their conscious or unconscious judgments related to the relationship that operates between their perception of work and their values, which is outlined in Castles, Haas and Miller (2017) and Kates and Tucker (2019) writings.

If the teaching profession as a whole is losing attractiveness in most regions of the world, we can conclude that educational institutions are uneven in their ability to retain and stabilize the staff.

\section{Discussion}

We have conducted a comparative analysis of foreign and Russian scientists' research distinguishing two types of migration: professional migration (horizontal vector) - when a 
teacher moves to another school-, and professional attrition-when a teacher changes profession. These two situations have the same consequences for an educational institution that loses a teacher. But it is very likely that motives underlying such behavior partially coincide.

Horizontal mobility is not only a phenomenon typical in the early years of a career, but it also applies to teachers who have passed the critical threshold for entry into the profession. The teaching profession differs from many other professions in that horizontal career paths are characterized by low job diversity at higher levels and hence a low probability of achieving vertical mobility. In general, after a few years of employment, the vast majority of teachers will stay in the profession for a long time.

Since a teacher spends most of their professional life in the classroom, the relationship maintained with pupils is of paramount importance in the personal professional development. Indeed, having a supportive climate between the teacher and the students for whom they are responsible is also an element that affects the rate of staff migration and attrition.

Thus, if we consider the migration of teachers in the economic aspect, it should be noted that federal funds will be used irrationally in such a phenomenon. Nevertheless, this process is conditioned by the difference in salaries. As Bondyreva and Kolesov (2007) said, migration is a problem of unmet needs.

When analyzing the literature and studies, it was found that a teacher who stays in the profession for more than one year will rarely look for another place of work or move to an outside site. At the same time, we have revealed that young personnel who, after one year in the profession, are distinguished by the desire to change the place of work or change the professional activity. Many authors see the reason in the low salary of a teacher: if we talk about small localities, the payment there is low; closer to large cities payment proportionally increases, but still cannot meet the level of a person covering all needs.

Let us compare the distinguishing features of the two definitions: labor migration and professional mobility. Labor migration is a type of migration; the aim of a person is to find a workplace with better characteristics; professional mobility is characterized by a person's ability to successfully master new knowledge in order to move from one activity to another. Thus, migration in general aspect affects the economic development of the country. The recovery and acceleration of the economy that happens due to the inflow of migrants depends on the extent to which the labor force is successfully integrated into society and is able to refuse state subsidies. If we talk about the outflow of migration, there is a risk of leakage of trained personnel at the expense of the state, which negatively affects the economy. 
From an individual perspective, beginner teachers show higher rates of migration and attrition than their more experienced colleagues. On both sides of the Atlantic, a large body of research has shown that early departures from the profession-both voluntary and involuntary - are essentially the result of an unreliable professional trajectory. In addition, teachers' initial training also affects their professional stability.

Stabilization of the teaching profession globally is becoming a key educational policy issue and a question of relevant research on teacher migration.

\section{Conclusion}

So, the comparative analysis of foreign and Russian academic literature has allowed us to reach the key goal of the research. We have disclosed the objectives of the article: distinguished the key problems of teacher migration; analyzed the works of Russian and foreign authors. In the academic article, we have found out that the topic we have chosen is urgent because the majority of scholars regard migration from the point of labor, educational, intellectual aspects, but separately the migration of teachers is found in the foreign authors' studies in a small extent. We believe that by studying the migration of teachers within the project "Study of migration of teachers and graduates of pedagogical universities between regions (causes, practices, consequences)", it will be possible to find levers and mechanisms to curb the outflow of young personnel.

All in all, the problem of specialists' dismissal and employees' migration between individual employers is a long-standing challenge, which is studied in scientific literature, especially in the field of management and human resources. Scientific works of foreign and Russian authors have made it possible to identify individual and organizational factors influencing the intention to leave a teacher's workplace. Studies of economic nature also tried to identify the role of incentives (financial) in decisions about career reorientation.

ACKNOWLEDGMENTS: The article was prepared within the framework of the state assignment of the Ministry of Education of the Russian Federation No. 073-03-2021-017/2 "Study of migration of teachers and graduates of pedagogical universities between regions (causes, practice, consequences)". 


\section{REFERENCES}

AMIROVA, D. R.; KHRAMOVA, A. I. Regulirovanie migracionnyh processov kak faktor obespečenija nacional'noj bezopasnosti strany [Regulation of migration processes as a factor of ensuring national security of the country]. Ėlektronnyj Naučno-Praktičeskij Žurnal «Sovremennye Naučnye Issledovanija i Innovacii» [Electronic Scientific and Practical Journal "Modern Scientific Research and Innovation"], Sochi, n. 6, p. 103-107, 2016. Available: https://web.snauka.ru/en/issues/2016/06/69052. Access: 8 Dec. 2021.

BAUMAN, Z. Work, consumerism and the new poor. Philadelphia: Open University Press, 2018.

BONDYREVA, S. K.; KOLESOV, D. V. Migraciya (sushhnost i yavlenie) [Migration (essence and phenomenon). Russia: Moscow, 2007.

BOURDIEU, P. Sociologiya socialnogo prostranstva [Sociology of Social Space]. Saint Petersburg: Aletheia, 2016.

CASTELLS, M. Informacionnaja èpoha: Èkonomika, obŝestvo i kul'tura [The information age: Economy, society and culture]. Translation: O. I. Shkaratan. Moscow: State University Higher School of Economics, 2020.

CASTLES, S.; HAAS, H.; MILLER, M. J. The age of migration: International population movements in the modern world. 5. ed. London: Palgrave, 2017.

DOLZHIKOVA, A. V. Intellektual'nyj kapital i intellektual'naja migracija v uslovijah globalizacii. Monografija [Intellectual Capital and Intellectual Migration in the Context of Globalization]. Moscow: Prospect, 2020.

GAGA, V. A. Èkonomika i sociologija truda: Social'no-trudovye otnošenija [Economics and sociology of labor: Social and labor relations]. Tomsk: Tomsk State University Publishing House, 2008.

GIMPELSON, V. E.; KAPELYUSHNIKOV, R. I. Mobil'nost'i stabil'nost' na rossijskom rynke truda [Mobility and stability in the Russian labor market]. Moscow: HSE Publishing House, 2017.

GORYUNOVA, L. V. Professional'naja mobil'nost' specialista kak problema razvivajuŝegosja obrazovanija Rossii [Professional mobility of a specialist as a problem of developing education in Russia]. 2006. Thesis (PhD in Pedagogical Sciences) - Rostov State Pedagogical Pedagogical University, Rostov-on-Don, 2006.

IGOSHEV, M. V. Self-preserving forms of migration. Current Issues of Economic Sciences, n. 50-51, p. 127-131, 2016.

JOHNSON, J. H.; SALT, J. Labour Migration: The internal geographical mobility of labour in the developed world. London: Routledge, 2018. DOI:

https://doi.org/10.4324/9780429398667 
KATES, S.; TUCKER, J. A. We never change, do we? Economic anxiety and far-right identification in a postcrisis Europe. Social Science Quarterly, Norman, v. 100, n. 2, p. 494523, 2019. DOI: https://doi.org/10.1111/ssqu.12597

KOVALEV, A. S. Migracionnaja politika v sovremennom mire [Migration policy in the modern world]. Krasnoyarsk: Astafiev State Pedagogical University, 2017.

MALYSHEV, E. A. Vnešnjaja trudovaja migracija v Rossijskoj Federacii: Teorija, istorija, administrativno-pravovye metody gosudarstvennogo upravlenija [External labor migration in the Russian Federation: Theory, history, administrative and legal methods of state management]. Moscow: Yurlitinform, 2015.

MCKENZIE, D.; STILLMAN, S.; GIBSON, J. How important is selection? Experimental and non-experimental measures of migration income gains. Journal of the European Economic Association, London, v. 8, n. 4, p. 913-945, 2010. DOI: https://doi.org/10.1111/j.15424774.2010.tb00544.x

MOISEENKO, V. M. Vnutrennjaja migracija naselenija [Internal migration of the population]. Moscow: TEIS, 2004.

NUZHNOVA, N. M. Podgotovka učitelej k rešeniju zadač Duhovno-nravstvennogo vospitanija $\mathrm{V}$ načal'nom obrazovanii S ispol'zovaniem kejs-stadi [Training teachers to solving the problems of spiritual and moral education in primary school using the case stage]. Nauka, Obrazovanie, Kul'tura [Science, Education, Culture], n. 2, p. 180-191, 2019.

PRONCHEV, G. B.; TRETIAKOVA, I. V.; LYUBIMOV, A. P.; PRONCHEVA, N. G. Osobennosti trudovoj migracii v sovremennoj Rossii [Peculiarities of labor migration in modern Russia]. Predstavitel'naja Vlast' - XXI vek: Zakonodatel'stvo, Kommentarii, Problemy [Representational Power - XXI Century: Legislation, Comments, Problems, v. 1-2, n. 168-169, p. 53-57, 2019.

SAVENKOV, A. I. Pedagogičeskaja psihologija v 2 č. Čast' 1. 3. ed. Moscow: Yurayt, 2016

SHCHERBAKOV, A. I. et al. Demografija [Demography]. Moscow: INFRA-M, 2017.

SOROKIN, P. A. Social'naja mobil'nost' [Social mobility]. Moscow: LVS, 2005.

TSKHADADZE, N. V.; SKRYABIN, K. A. [Migration of labor resources in Russia]. Russia: Research Institute of Economics of the South Federal District, 2020. In Russian.

UTKINA, V. A.; SLIUSARENKO, V. K. [The essence of the concept of "migration"]. Molodoj Učënyj [Young Scientist], v. 30, n. 134, p. 282-284, 2016. In Russian.

VERSHININA, I. A. Migracionnye processy v uslovijah globalizacii: Sociologičeskij analiz faktorov $i$ tendencij razvitija [Migration processes in the context of globalization: A sociological analysis of factors and development trends]. 2006. Thesis.

VOLKOV, Y. E. Sociologija truda [Sociology of Labor]. Moscow: ATISO, 2009. 
ZHELTOV, V. V.; SKORNYAKOV, I. A. Migracija kak predposylka social'nyh konfliktov [Migration as a prerequisite for social conflicts]. Kaspijskij Region: Politika, Èkonomika, Kul'tura [The Caspian Region: Politics, Economy, Culture], n. 4, p. 10-14, 2008. Available: https://kaspy.asu.edu.ru/?articleId=1700\&lang=en. Access: 8 Dec. 2021.

\section{How to reference this article}

KOLESNIKOVA I.; BOGOMOLOVA, A.; FEDINA, N.; BURMYKINA, I.; KATAEV, D.; ZEMLYANSKAYA, A. Comparative analysis of the teachers' migration. Revista online de Política e Gestão Educacional, Araraquara, v. 25, n. 3, p. 2379-2392, Sep./Dec. 2021. e-ISSN: 1982-5587. DOI: https://doi.org/10.22633/rpge.v25i2.15924

Submitted: $23 / 09 / 2021$

Required revisions: $21 / 10 / 2021$

Approved: 19/11/2021

Published: 08/12/2021 